\title{
Influence of Mineral Fertilization on the Capacity of Nodulation of Three Species of Legumes (Groundnut, Cowpea and Soybean)
}

\author{
Kouassi N'dri Jacob ${ }^{1 *}$, Kouame N'guessan ${ }^{1}$, Alui Konan Alphonse ${ }^{2}$, \\ Yao Koffi Joël1 ${ }^{1}$, Ayolie Koutoua' ${ }^{1}$, Yatty Kouadio Justin ${ }^{1}$ \\ ${ }^{1}$ Laboratory of Improvement of Agricultural Production, University Jean Lorougnon GUEDE, Agroforestry UFR, Daloa, \\ Côte d'Ivoire \\ ${ }^{2}$ Geosciences Department, University Péléforo Gbon Coulibaly, Biological SciencesUFR, Korhogo, Côte d'Ivoire \\ Email: *kouassindrijacob@yahoo.fr
}

How to cite this paper: Jacob, K.N., N'guessan, K., Alphonse, A.K., Joël, Y.K., Koutoua, A. and Justin, Y.K. (2019) Influence of Mineral Fertilization on the Capacity of Nodulation of Three Species of Legumes (Groundnut, Cowpea and Soybean). American Journal of Plant Sciences, 10 , 2208-2218.

https://doi.org/10.4236/ajps.2019.1012156

Received: November 14, 2019

Accepted: December 17, 2019

Published: December 20, 2019

Copyright $\odot 2019$ by author(s) and Scientific Research Publishing Inc. This work is licensed under the Creative Commons Attribution International License (CC BY 4.0).

http://creativecommons.org/licenses/by/4.0/ (c) (i) Open Access

\begin{abstract}
Groundnut (Arachis hypogaea), cowpea (Vigna unguiculata) and soybean (Vigna radiata) are the main food legumes grown in Côte d'Ivoire and the localities of Haut-Sassandra. These legumes are highly valued for their nutritional, agronomic and economic value. Groundnut, cowpea and soybean are the main food legumes grown in Côte d'Ivoire and in the localities of Haut-Sassandra. On the other hand, Ivorian soils are characterized by a tendency towards acidification and a decrease in the content of nutrients such as phosphorus and nitrogen which have a direct impact on the products. To restore soil fertility, farmers use mineral fertilization. However, this fertilization has an influence on the nodulation of these legumes. The study took place at Jean Lorougnon University. We adopted a completely random experimental block device. The parameters measured included the number of nodules, the length and weight of the plant, the length and weight of the root system. Our results showed that mineral fertilization reduced the nodulation capacity of legumes. However, a small dose of phosphorus $(<2 \mathrm{~g})$ would be required for early growing legumes.
\end{abstract}

\section{Keywords}

Mineral Fertilization, Legumes, Nodulation, Phosphorus

\section{Introduction}

In rotational cropping systems, legume-fixed nitrogen can be used first by the legumes and then by subsequent crops [1]. Legumes are considered as plants 
that can protect soils from degradation [2]. Despite their recognized role in terms of improved performance, legumes occupy a marginal place in cropping systems in Côte d'Ivoire in favor of the coffee-cocoa duo. But today, in the face of the population growth and imperatives of food self-sufficiency, food crops such as sustenance legumes are becoming important. These crops now play a key role in intercommunity trade. In addition, they produce a wide range of agricultural products that can improve household diets. Moreover, they can be associated with industrial crops and the revenues from the marketing guarantee the economic accessibility to other foodstuffs. Among these legumes, cowpea (Vigna unguiculata $(L)$ walp), groundnut (Arachis hypogaea) and green soybean (Vigna radiata) are the most important in most African communities where they are grown [3]. These plants also play a major role in human nutrition because of the quality of the proteins contained in their seeds.

Despite their nutritional and agricultural importance, legumes' yields are still low in our country. This low yield can result from the control of the quality of the sufficient information, the quality of cultural practice and especially the decline in fertility [4]. Also, mineral fertilization has an impact on the nodulation capacity of legumes. High soil nitrogen levels have been shown to reduce nodulation and nitrogen fixation [5]. Some studies have shown that phosphorus, dolomite and manure increase nodulation [6]. Similarly, the lack of phosphorus in soil reduces the number and mass of nodules as well as the activity of nitrogenase in legumes [7]. Yet, other studies have shown that NPK mineral fertilization, especially chicken manure, does not influence the number and weight of nodules [8]. The overall objective of this study is to promote a cultural practice that can improve the nodulation capacity of legumes. The study consists of fertilizing at different doses the soil with three species of legumes grown alone or in combination to check if:

- fertilization influences the agronomic parameters of legumes;

- there are fertilizer doses to increase the nodulation of the three legumes alone or in combination.

\section{Material and Methods}

\subsection{Study Site}

The study was carried out on an experimental plot in the locality of Daloa. The city of Daloa is located in the Upper Sassandra region of west-central Côte

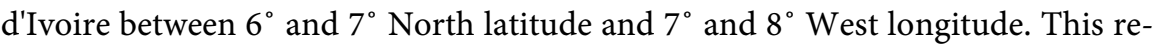
gion has an area of $15,200 \mathrm{~km}^{2}$ for an estimated population of $1,430,960$ inhabitants. The department of Daloa is bounded in the North by the departments of Vavoua and Zuénoula, in the South by those of Issia and Sinfra, in the west the county districts of Duékoué and Bangolo and in the East by that of Bouaflé. It covers an area of $5423 \mathrm{~km}^{2}$, comprising 137 localities and 6 sub-prefectures (Figure 1). The climate has four seasons. The long rainy season starts from April to mid-July, the short dry season from mid-July to mid-September, the short 
rainy season from mid-September to mid-November and the long dry season from December to March. The wet and dry seasons alternate with temperatures ranging from $24.65^{\circ} \mathrm{C}$ to $27.75^{\circ} \mathrm{C}$ on average. Rainfall, temperature and average humidity characterizing the study site in the test periods from May to August 2016 corresponding to the major rainy seasons are respectively: $142.81 \mathrm{~mm}$; $26.42^{\circ} \mathrm{C}$ and $83.7 \mathrm{~g} / \mathrm{m}^{2}$.

\subsection{Plant Material}

The plant material used in this study consisted of three legume species from the Jean Lorougnon Guédé University collection. It is between the other Vigna unguiculata, Vigna radiata and Arachis hypogaea (Figure 2). The choice of these

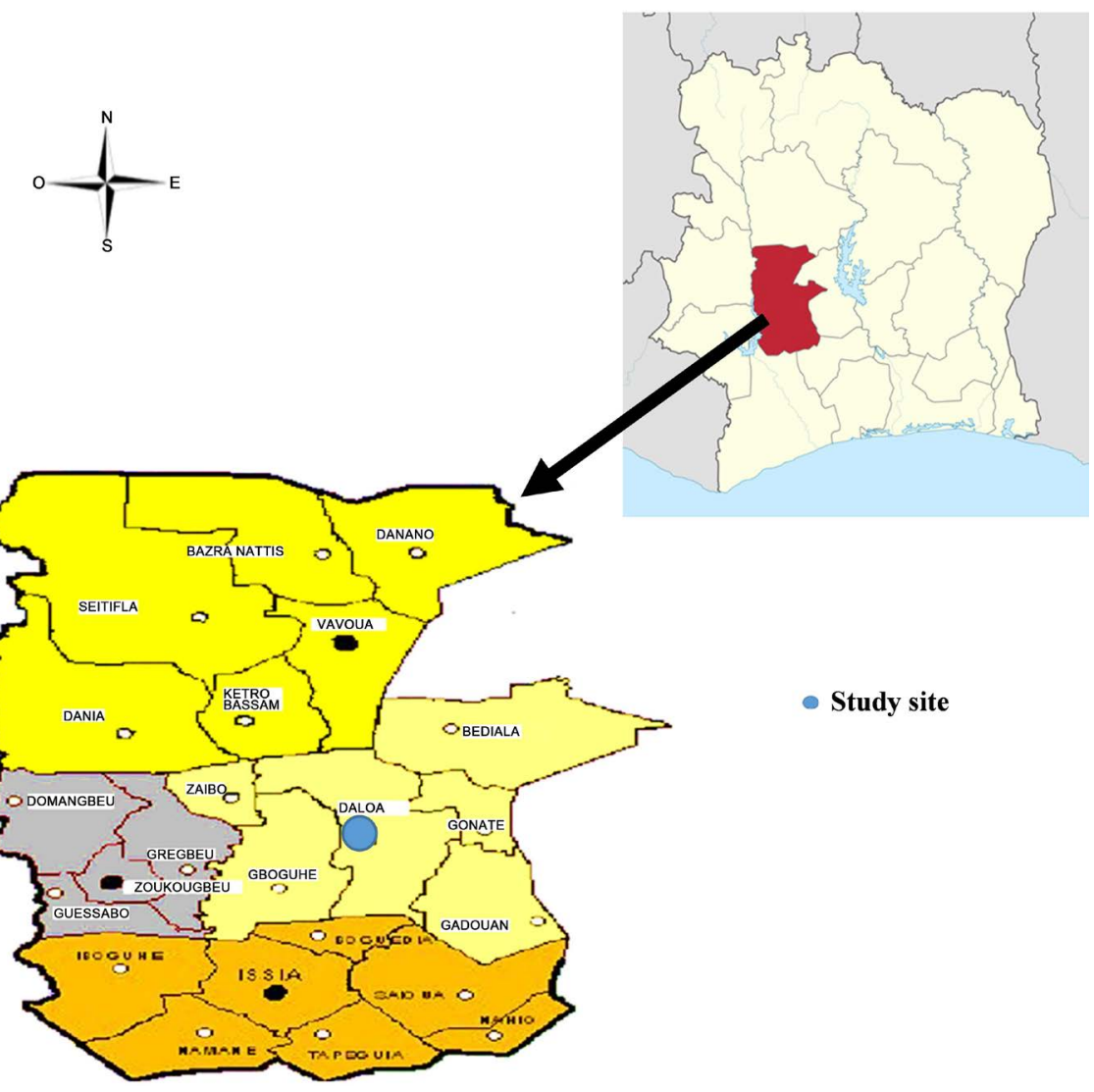

Figure 1. Presentation of the study zone.

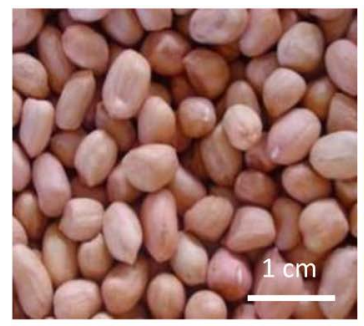

(a)

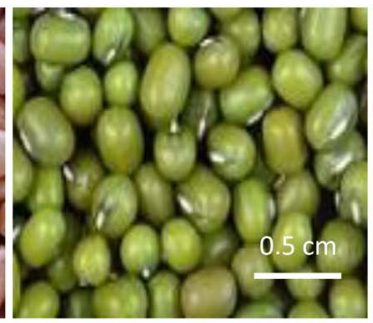

(b)

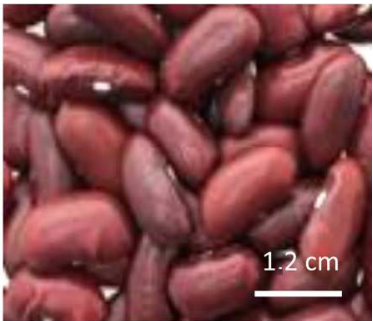

(c)

Figure 2. Plant material. (a) Groundnut (Arachis hypogaea), (b) Green soy (Vigna radiata) and (c) Cowpea (Vigna unguiculata). 
three species is due to the fact that they are more cultivated and consumed in the Upper Sassandra region.

\subsection{Methods}

\subsubsection{Experimental Apparatus}

The experimental device used is that of completely randomized blocks with three repetitions. A plot of $5 \mathrm{~m}^{2}$ was divided into 3 blocks distant from each other by $0.5 \mathrm{~m}$. Each block consists of 28 elementary batches spaced $0.05 \mathrm{~m}$ apart. Each lot consists of 5 pots. These pots are actually bags of black polyethylene 80 microns thick, $25 \mathrm{~cm}$ high and $12 \mathrm{~cm}$ wide flat. They are filled with earth $7.5 \mathrm{~cm}$ in diameter and $21 \mathrm{~cm}$ high, a volume of one liter and a weight of about $1.2 \mathrm{~kg}$. The lots are arranged in 4 rows per block. Each row corresponds to a single dose of nitrogen, phosphorus or nitrogen-phosphorus mixture ( $0 \mathrm{~g}$, $2 \mathrm{~g}, 4 \mathrm{~g}$ or $6 \mathrm{~g}$ ) (Figure 3). Seedlings were carried out on January 6, 2018 which is a season of light rains. The rows were arranged in groups. The first group (G1) consists of lots with only one species in each pot (peanut, cowpea or soy). The second group (G2) consists of lots with the association of two species in each pot (peanut-cowpea, peanut-soy or soybean-cowpea). The third group (G3) consists of the lots comprising the association of the three species in each pot (peanut-cowpea-soya). To increase the chances of germination, three seeds of each species were sown per pot. All seeds were sown $1 \mathrm{~cm}$ deep. Watering was done every morning and evening with tap water. The removal was done ten days after sowing in order to preserve the best plants per pot. An insecticide treatment with cypercal 50 EC (cypermethrin $50 \mathrm{~g} / \mathrm{l}$ ) was carried out 3 weeks after sowing.

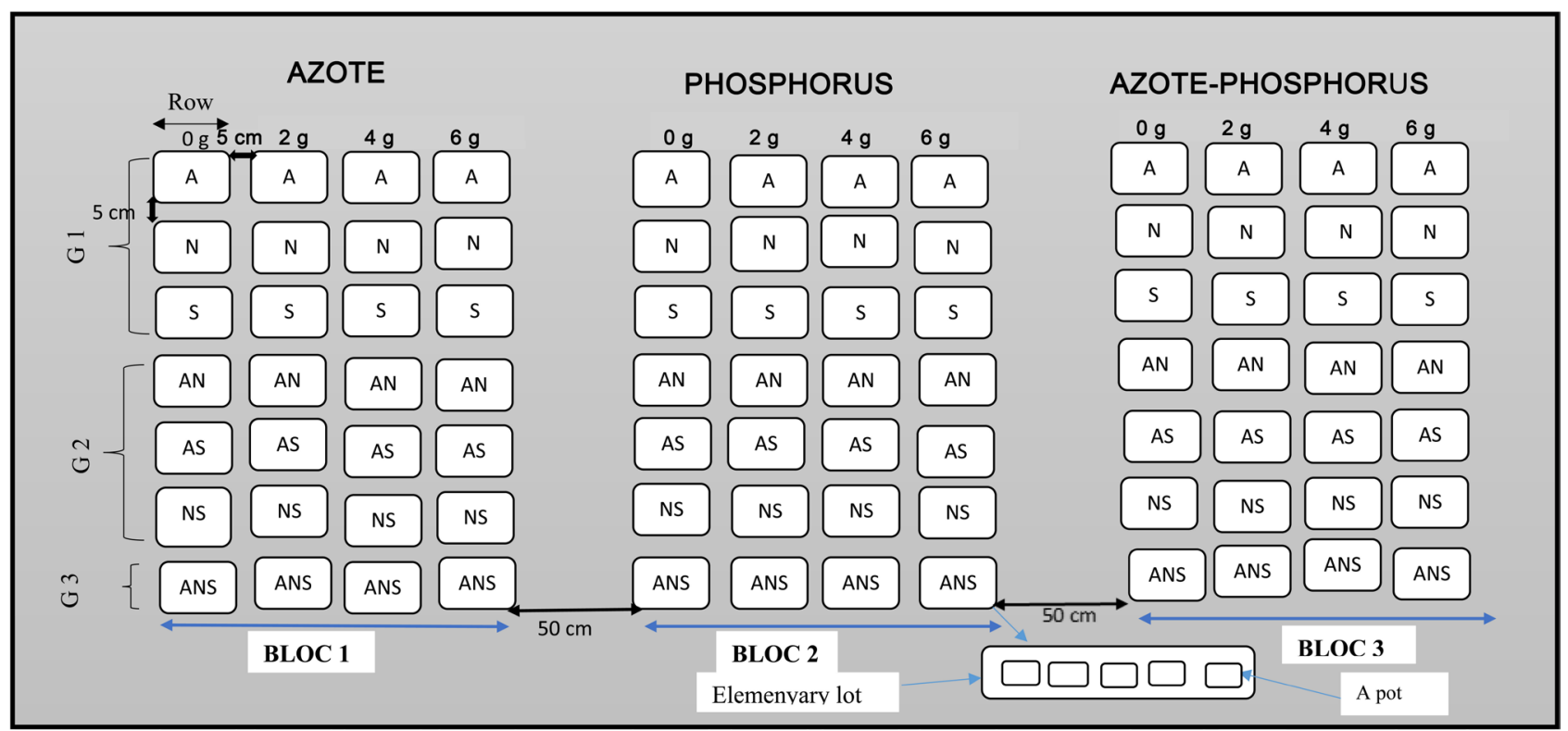

A: groundnut without treatment, AN: groundnut associated with cowpea without fertilizer, AS: groundnut associated with soy without fertilizer, ANS: groundnut associated with cowpea and soy without treatment, AT: groundnut with treatment, AST: groundnut associated with soy with treatment, ANT: groundnut associated with cowpea under treatment, ANST: groundnut associated with cowpea and soya under treatment.

Figure 3. Schematic of the experimental device. 


\subsubsection{Collection of Data}

All data were collected six weeks after sowing corresponding to the flowering period. They concerned the number of nodules, the length of the plant and that of the root system, the weight of the plant and that of the root system. All measurements were taken on three feet of each lot taken at random for each species. However, care must be taken to avoid the cutting of secondary roots and the loss of nodules detached from the roots by ridding the plants of the bags. The root of the plants is soaked in water to better see and count the nodules measurements began with the counting of nodules which consisted in giving the number of nodules on the root system of the plant. The length of the plant consisted in measuring the distance of the main stem from the neck to the most extreme leaf. That of the root system from the neck to the end of the root. They were measured using a tape measure. The root system was separated from the plant and its weight was determined using a precision Howell scale $5 \mathrm{~kg} \times 1 \mathrm{~g}$. The weight of the plant was also determined.

\subsubsection{Statistical Analysis}

The data collected for each of the 5 variables were entered with the Excel spreadsheet version 97-2003 and then processed taking into account the species and the fertilizer using the STATISTICA version 7.1 software through analysis of variance (ANOVA). The significance of the test was determined by comparing the probability (P) associated with the threshold statistic $\alpha=0.05$. When a significant difference was observed between the characters, the ANOVA was supplemented by the Smallest Significant Difference (LSD) test. SDPP allows you to see homogeneous groups, since it tells us where this significant difference is. This analysis of variance makes it possible to note the significant differences between the species and the mineral fertilizers considered.

\section{Results and Discussion}

\subsection{Results}

\subsubsection{Effect of Mineral Fertilization on Agronomic Parameters of Groundnut}

The results of the analysis of variance indicate that agronomic parameters were influenced by mineral fertilization. Significant differences were observed in all fertilizer rates applied to groundnut for all agronomic parameters (Table 1). In fact, the highest number of nodules was obtained in groundnut grown without the use of mineral fertilizers $(59.83 \pm 24.2)$ (Figure $4(a))$, when the smallest number of nodules was obtained at groundnut grown with 6 grams of nitrogen (2.00 \pm 6.9$)$ (Figure 4(b)).

Measurements made on the length of the plant showed that groundnuts grown with $2 \mathrm{~g}$ of nitrogen recorded the highest average (16.75 \pm 21.6$)$, while that cultivated with $4 \mathrm{~g}$ of nitrogen had the highest average low average (6.41 \pm 5.2). The length of the plant is significantly identical for groundnut grown with 6 $\mathrm{g}$ of nitrogen, phosphorus ( $2 \mathrm{~g}, 4 \mathrm{~g}$ and $6 \mathrm{~g}$ ), the nitrogen-phosphorus mixture (2 
Table 1. Statistical analysis of agronomic parameters measured on groundnuts grown at different doses of mineral fertilizers.

\begin{tabular}{|c|c|c|c|c|c|c|c|c|c|c|c|c|}
\hline \multirow{2}{*}{ Variables } & \multicolumn{10}{|c|}{ Averages ( \pm gap-type) } & \multicolumn{2}{|c|}{ Statistics } \\
\hline & $2 \mathrm{gN}$ & $4 \mathrm{gN}$ & $6 \mathrm{gN}$ & $2 \mathrm{gP}$ & $4 \mathrm{gP}$ & $6 \mathrm{gP}$ & $2 \mathrm{gNP}$ & $4 \mathrm{gNP}$ & $6 \mathrm{gNP}$ & Do & $\mathrm{F}$ & $\mathbf{P}$ \\
\hline L. $p(\mathrm{~cm})$ & $16.75 \pm 21.6^{c}$ & $6.41 \pm 5.2^{\mathrm{a}}$ & $9.25 \pm 3.9^{b}$ & $10.91 \pm 3.3^{\mathrm{b}}$ & $10.41 \pm 3.8^{\mathrm{b}}$ & $9.75 \pm 2.9^{\mathrm{b}}$ & $9.00 \pm 2.8^{\mathrm{b}}$ & $8.50 \pm 2.4^{\mathrm{b}}$ & $6.66 \pm 3.3^{b}$ & $13.66 \pm 5.0^{\mathrm{b}}$ & 1.9 & 0.0 \\
\hline P. $p(g)$ & $40.14 \pm 29.9^{b}$ & $18.15 \pm 13.6^{\mathrm{a}}$ & $19.26 \pm 9.2^{\mathrm{a}}$ & $43.87 \pm 27.0^{b}$ & $46.10 \pm 29.5^{b}$ & $37.33 \pm 25.3^{b}$ & $36.47 \pm 18.0^{b}$ & $29.46 \pm 19.6^{\mathrm{a}}$ & $25.93 \pm 11.0^{\mathrm{a}}$ & $60.08 \pm 32.3^{c}$ & 3.9 & 0.0 \\
\hline L. SR (cm) & $36.08 \pm 15.3^{e}$ & $15.66 \pm 12.3^{\mathrm{a}}$ & $22.16 \pm 6.4^{\mathrm{b}}$ & $28.00 \pm 3.9^{d}$ & $35.75 \pm 8.7^{e}$ & $32.33 \pm 9.4^{\mathrm{d}}$ & $30.50 \pm 6.6^{d}$ & $34.08 \pm 7.3^{\mathrm{e}}$ & $27.41 \pm 5.8^{c}$ & $29.50 \pm 8.0^{\mathrm{d}}$ & 6.0 & 0.0 \\
\hline P. SR (g) & $9.56 \pm 8.3^{\mathrm{a}}$ & $6.86 \pm 8.2^{\mathrm{a}}$ & $9.66 \pm 5.9^{\mathrm{a}}$ & $10.76 \pm 7.3^{\mathrm{a}}$ & $8.73 \pm 5.4^{\mathrm{a}}$ & $8.73 \pm 5.7^{\mathrm{a}}$ & $12.67 \pm 6.7^{\mathrm{a}}$ & $9.06 \pm 4.9^{\mathrm{a}}$ & $7.81 \pm 3.8^{\mathrm{a}}$ & $11.95 \pm 6.8^{\mathrm{a}}$ & 0.9 & 0.5 \\
\hline
\end{tabular}

For each variable, values with the same letters on the line are statistically equal. $\mathbf{2}$ gN: two grams of nitrogen, $\mathbf{4}$ gN: four grams of nitrogen, $\mathbf{6}$ gN: six grams of nitrogen, $2 \mathrm{gP}$ : two grams of phosphorus, $4 \mathrm{gP}$ : four grams of phosphorus, $6 \mathrm{gP}$ : six grams of phosphorus, 2 gNP: two grams of Nitrogen-phosphorus mixture, 4 gNP: four grams of the nitrogen-phosphorus mixture, 6 gNP: six grams of the nitrogen-phosphorus mixture, D0: zero dose. N.NOD: Number of nodules, L. p. (cm): Length of the plant, P. p. (g): Weight of the plant, L. SR (cm): Length of the root system, P. SR (g): Weight of the root system.

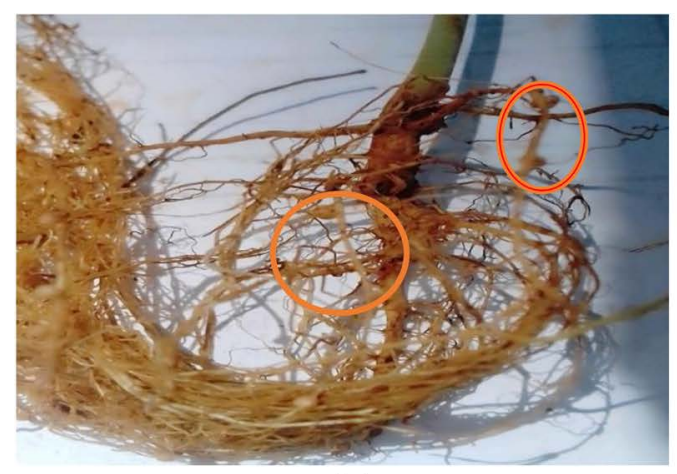

(a)

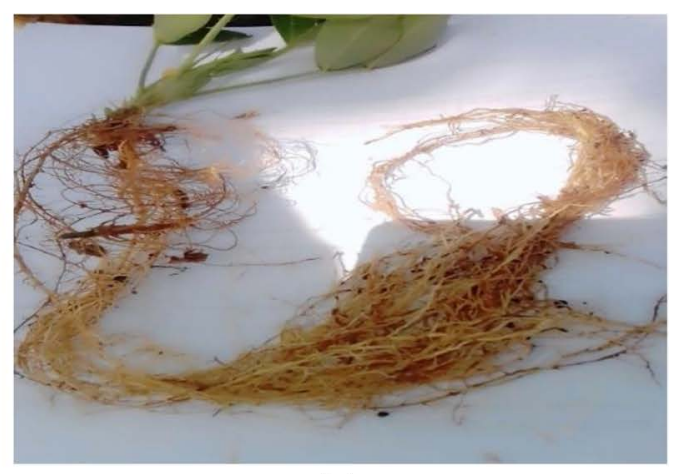

(b)

Figure 4. Photography showing the influence of mineral fertilization on the nodulation capacity of groundnut. (a) groundnut grown without mineral fertilizers; (b) fertilized groundnut.

$\mathrm{g}, 4 \mathrm{~g}$ and $6 \mathrm{~g}$ ) and of that cultivated without the use of mineral fertilizers. As for the weight of the plant, the highest average was obtained in groundnut cultivated without the use of mineral fertilizers $(60.08 \pm 32.3)$, while the lowest average was recorded at the level of $4 \mathrm{~g}$. nitrogen $(18.15 \pm 13.6)$. Groundnuts grown with $2 \mathrm{~g}$ of nitrogen, phosphorus ( $2 \mathrm{~g}, 4 \mathrm{~g}$ and $6 \mathrm{~g}$ ) and $2 \mathrm{~g}$ of nitrogen-phosphorus are significantly identical. In terms of the length of the root system, peanuts grown with $2 \mathrm{~g}$ of nitrogen gave the highest average ( $36.08 \pm 15.3$ ), while the lowest average was obtained in groundnut cultivated with $4 \mathrm{~g}$ of nitrogen (15.66 \pm 12.3 ). The length of the root system is significantly identical for groundnuts grown with $2 \mathrm{~g}$ of phosphorus, $6 \mathrm{~g}$ of phosphorus, $2 \mathrm{~g}$ of nitrogen-phosphorus and that grown without the use of mineral fertilizers. The weight of the root system showed no significant difference for peanuts grown with or without mineral fertilizers.

\subsubsection{Effect of Mineral Fertilization on the Agronomic Parameters of Cowpea}

Variables such as number of nodules, plant length, plant weight, length of root system and root system weight in cowpea were measured and analyzed in relation to mineral fertilization. Results from statistical analyze showed a significant 
difference between the different doses of mineral fertilization (Table 2). In fact, cowpea grown without the use of mineral fertilizers recorded the highest number of nodules ( $35.91 \pm 27.4$ ) (Figure $5(\mathrm{a})$ ), yet the smallest number of nodules was obtained at the $2 \mathrm{~g}$ level nitrogen-phosphorus $(0.00 \pm 0.0)$ (Figure 5(b)). The results of the analyze showed that cowpea grown without mineral fertilizers had the highest plant length $(16.69 \pm 3.3)$, while that grown with $2 \mathrm{~g}$ of nitrogen-phosphorus had the shortest length of the plant. The plant $(4.91 \pm 3.5)$. The length of the plant is significantly identical for cowpea grown with $6 \mathrm{~g}$ of nitrogen and $6 \mathrm{~g}$ of nitrogen-phosphorus as well as for that grown with $6 \mathrm{~g}$ of phosphorus and $4 \mathrm{~g}$ of nitrogen-phosphorus. The cowpea grown with $6 \mathrm{~g}$ of nitrogen, $4 \mathrm{~g}$ of nitrogen-phosphorus and $6 \mathrm{~g}$ of nitrogen-phosphorus are significantly identical for the weight of the plant, as is that cultivated with $2 \mathrm{~g}$ of nitrogen, $2 \mathrm{~g}$ of phosphorus and $6 \mathrm{~g}$ of phosphorus. Cowpea grown with $2 \mathrm{~g}$ of phosphorus nitrogen expressed the highest average $(47.81 \pm 6.1)$, at the time when the lowest average was obtained in cowpea grown with $4 \mathrm{~g}$ of phosphorus $(6.81 \pm 5.2)$ Measurements made along the length of the root system have shown that cowpea grown without the use of mineral fertilizers has a high average $(28.75 \pm$ 10.2), or that grown with $6 \mathrm{~g}$ of nitrogen-phosphorus has the lowest average $(11.66 \pm 7.6)$. The length of the root system is significantly identical for cowpea

Table 2. Statistical analysis of agronomic parameters measured on cowpea grown at different doses of mineral fertilizers.

\begin{tabular}{|c|c|c|c|c|c|c|c|c|c|c|c|c|}
\hline \multirow{2}{*}{ Variables } & \multicolumn{10}{|c|}{ Averages ( \pm gap-type) } & \multicolumn{2}{|c|}{ Statistics } \\
\hline & $2 \mathrm{gN}$ & $4 \mathrm{gN}$ & $6 \mathrm{gN}$ & $2 \mathrm{gP}$ & $4 \mathrm{gP}$ & $6 \mathrm{gP}$ & $2 \mathrm{gNP}$ & 4 gNP & $6 \mathrm{gNP}$ & Do & $\mathbf{F}$ & $\mathbf{P}$ \\
\hline L. $p(\mathrm{~cm})$ & $9.66 \pm 4.2^{c}$ & $13.77 \pm 4.5^{\mathrm{f}}$ & $8.14 \pm 6.0^{\mathrm{b}}$ & $11.50 \pm 3.4^{\mathrm{e}}$ & $16.58 \pm 1.5^{\mathrm{g}}$ & $11.00 \pm 4.2^{\mathrm{d}}$ & $4.91 \pm 3.5^{\mathrm{a}}$ & $10.66 \pm 3.9^{\mathrm{d}}$ & $7.38 \pm 5.1^{\mathrm{b}}$ & $16.69 \pm 3.3^{\mathrm{g}}$ & 10.0 & 0.0 \\
\hline P. p (g) & $25.85 \pm 19.4^{\mathrm{c}}$ & $38.81 \pm 26.1^{\mathrm{e}}$ & $15.68 \pm 17.6^{\mathrm{b}}$ & $24.75 \pm 16.7^{\mathrm{c}}$ & $47.81 \pm 6.1^{\mathrm{f}}$ & $25.11 \pm 14.8^{c}$ & $6.81 \pm 5.2^{\mathrm{a}}$ & $17.11 \pm 14.7^{\mathrm{b}}$ & $8.88 \pm 7.7^{b}$ & $29.75 \pm 21.4^{\mathrm{d}}$ & 7.2 & 0.0 \\
\hline L. SR (cm) & $16.88 \pm 8.8^{\mathrm{b}}$ & $23.91 \pm 11.7^{\mathrm{d}}$ & $15.66 \pm 12.5^{\mathrm{b}}$ & $18.50 \pm 4.5^{c}$ & $20.58 \pm 5.1^{c}$ & $18.25 \pm 4.0^{c}$ & $13.33 \pm 8.3^{\mathrm{b}}$ & $16.33 \pm 6.4^{\mathrm{b}}$ & $11.66 \pm 7.6^{\mathrm{a}}$ & $28.75 \pm 10.2^{\mathrm{e}}$ & 4.2 & 0.0 \\
\hline P. SR (g) & $7.09 \pm 6.2^{c}$ & $11.35 \pm 9.2^{\mathrm{e}}$ & $3.96 \pm 4.1^{c}$ & $7.20 \pm 6.2^{c}$ & $9.75 \pm 5.0^{\mathrm{d}}$ & $6.93 \pm 4.0^{\mathrm{e}}$ & $2.03 \pm 1.2^{\mathrm{a}}$ & $5.12 \pm 3.6^{\mathrm{c}}$ & $2.56 \pm 2.1^{\mathrm{b}}$ & $10.91 \pm 8.8^{e}$ & 4.0 & 0.0 \\
\hline
\end{tabular}

For each variable, values with the same letters on the line are statistically equal. $\mathbf{2} \mathbf{g N}$ : two grams of nitrogen, $\mathbf{4} \mathrm{gN}$ : four grams of nitrogen, $\mathbf{6} \mathrm{gN}$ : six grams of nitrogen, 2 gP: two grams of phosphorus, $\mathbf{4}$ gP: four grams of phosphorus, $\mathbf{6}$ gP: six grams of phosphorus, 2 gNP: two grams of Nitrogen-phosphorus mixture, $\mathbf{4}$ gNP: four grams of the nitrogen-phosphorus mixture, 6 gNP: six grams of the nitrogen-phosphorus mixture, D0: zero dose. N. NOD: Number of nodules, L.p. (cm): Length of the plant, P. p. (g): Weight of the plant, L. SR (cm): Length of the root system, P. SR (g): Weight of the root system.

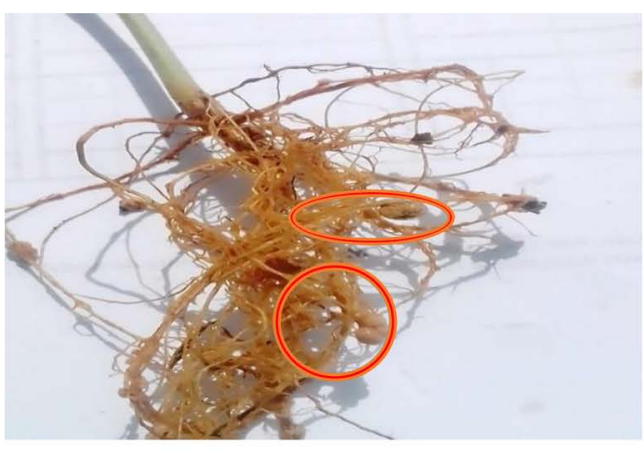

(a)

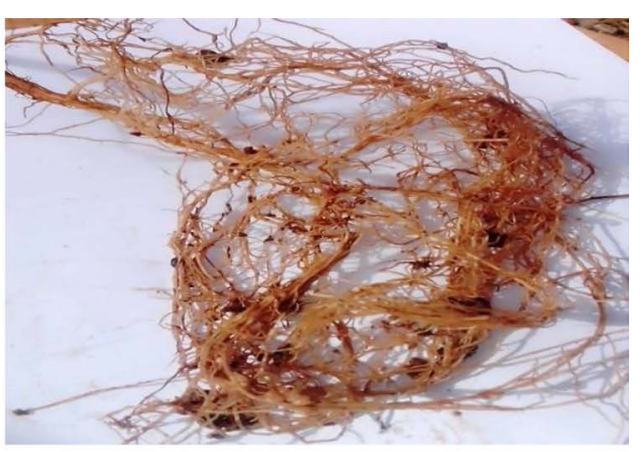

(b)

Figure 5. Photography showing the influence of mineral fertilization on the nodulation capacity of cowpea. (a) Cowpea grown without fertilizers; (b) fertilized cowpea. 
grown with $2 \mathrm{~g}$ of nitrogen, $6 \mathrm{~g}$ of nitrogen, $2 \mathrm{~g}$ of nitrogen-phosphorus, $4 \mathrm{~g}$ of nitrogen-phosphorus and that grown with phosphorus $(2 \mathrm{~g}, 4 \mathrm{~g}$ and $6 \mathrm{~g})$.

With regard to the weight of the root system, cowpea grown with $2 \mathrm{~g}$ of nitrogen was distinguished by its high average $(11.35 \pm 9.2)$ while that cultivated with $2 \mathrm{~g}$ of nitrogen-phosphorus recorded the lower average $(2.03 \pm 1.2)$. The weight of the root system is significantly identical between cowpea grown with $2 \mathrm{~g}$ of nitrogen, $6 \mathrm{~g}$ of nitrogen, $2 \mathrm{~g}$ of phosphorus and $4 \mathrm{~g}$ of nitrogen-phosphorus.

\subsubsection{Effect of Mineral Fertilization on the Agronomic Parameters of Soybeans}

The result of the statistical analysis of the data presented in Table 3 showed that variables such as the number of nodules, the length of the plant, the weight of the plant, the length of the root system and the root system weight of the soybeans were influenced by mineral fertilization. In fact, the measurements made on the number of nodules and the length of the plant showed that the highest averages were recorded for soybeans grown without mineral fertilizers respectively (22.08 \pm 16.91 and $23.25 \pm 4.88$ ) (Figure 6(a)) while the lowest averages were obtained

Table 3. Statistical analysis of agronomic parameters measured on soybean grown at different doses of mineral fertilizers.

\begin{tabular}{|c|c|c|c|c|c|c|c|c|c|c|c|c|}
\hline \multirow{2}{*}{ Variables } & \multicolumn{10}{|c|}{ Averages ( \pm gap-type) } & \multicolumn{2}{|c|}{ Statistics } \\
\hline & $2 \mathrm{gN}$ & $4 \mathrm{gN}$ & $6 \mathrm{gN}$ & $2 \mathrm{gP}$ & $4 \mathrm{gP}$ & $6 \mathrm{gP}$ & $2 \mathrm{gNP}$ & $4 \mathrm{gNP}$ & $6 \mathrm{gNP}$ & D0 & $\mathbf{F}$ & $\mathbf{P}$ \\
\hline L. $\mathrm{p}(\mathrm{cm})$ & $12.58 \pm 7.83^{\mathrm{b}}$ & $14.70 \pm 7.21^{\mathrm{c}}$ & $11.12 \pm 8.55^{\mathrm{b}}$ & $17.45 \pm 5.13^{\mathrm{c}}$ & $20.70 \pm 5.66^{\mathrm{d}}$ & $13.58 \pm 9.54^{c}$ & $7.89 \pm 6.28^{\mathrm{a}}$ & $10.83 \pm 10.63^{\mathrm{a}}$ & $8.88 \pm 5.70^{\mathrm{a}}$ & $23.25 \pm 4.88^{\mathrm{e}}$ & 5.54 & 0.00 \\
\hline P. $p(g)$ & $13.91 \pm 12.88^{\mathrm{a}}$ & $11.28 \pm 11.54^{\mathrm{a}}$ & $15.05 \pm 23.70^{\mathrm{a}}$ & $10.05 \pm 8.48^{\mathrm{a}}$ & $13.06 \pm 8.10^{\mathrm{a}}$ & $6.28 \pm 6.79^{\mathrm{a}}$ & $6.87 \pm 12.03^{\mathrm{a}}$ & $4.88 \pm 6.99^{\mathrm{a}}$ & $3.42 \pm 3.49^{\mathrm{a}}$ & $17.28 \pm 15.33^{\mathrm{a}}$ & 1.77 & 0.08 \\
\hline $\begin{array}{l}\text { L. SR } \\
(\mathrm{cm})\end{array}$ & $13.58 \pm 9.94^{\mathrm{a}}$ & $16.23 \pm 10.18^{b}$ & $13.41 \pm 13.74^{\mathrm{a}}$ & $18.66 \pm 6.00^{\mathrm{b}}$ & $20.50 \pm 4.75^{\mathrm{b}}$ & $12.58 \pm 8.47^{\mathrm{a}}$ & $11.43 \pm 10.72^{\mathrm{a}}$ & $10.50 \pm 11.16^{\mathrm{a}}$ & $14.66 \pm 10.28^{\mathrm{a}}$ & $28.16 \pm 9.42^{c}$ & 3.52 & 0.00 \\
\hline P. SR (g) & $2.12 \pm 1.88^{\mathrm{a}}$ & $2.07 \pm 3.01^{\mathrm{a}}$ & $2.90 \pm 5.42^{\mathrm{a}}$ & $1.62 \pm 1.46^{\mathrm{a}}$ & $1.82 \pm 1.41^{\mathrm{a}}$ & $0.99 \pm 1.19^{\mathrm{a}}$ & $1.67 \pm 3.35^{\mathrm{a}}$ & $0.56 \pm 0.80^{\mathrm{a}}$ & $0.61 \pm 0.75^{\mathrm{a}}$ & $3.79 \pm 3.41^{\mathrm{a}}$ & 1.29 & 0.24 \\
\hline
\end{tabular}

For each variable, values with the same letters on the line are statistically equal. $\mathbf{2} \mathbf{g N}$ : two grams of nitrogen, $\mathbf{4}$ gN: four grams of nitrogen, $\mathbf{6}$ gN: six grams of nitrogen, $2 \mathrm{gP}$ : two grams of phosphorus, $\mathbf{4} \mathrm{gP}$ : four grams of phosphorus, $\mathbf{6} \mathrm{gP}$ : six grams of phosphorus, $\mathbf{2}$ gNP: two grams of the nitrogen-phosphorus mixture, $4 \mathrm{gNP}$ : four grams of the nitrogen-phosphorus mixture, $6 \mathrm{gNP}$ : six grams of the nitrogen-phosphorus mixture, DO: Zero dose. N. NOD: Number of modules, L. P. (cm): lenght of the plant, P.p.(g):weight of the plant, L. SR(cm): Lenght of the root of the root system, P. SR (g): weight of the root system.

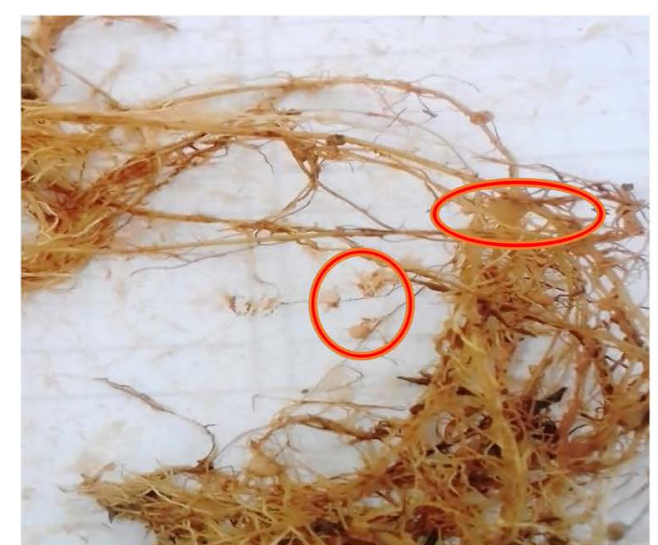

(a)

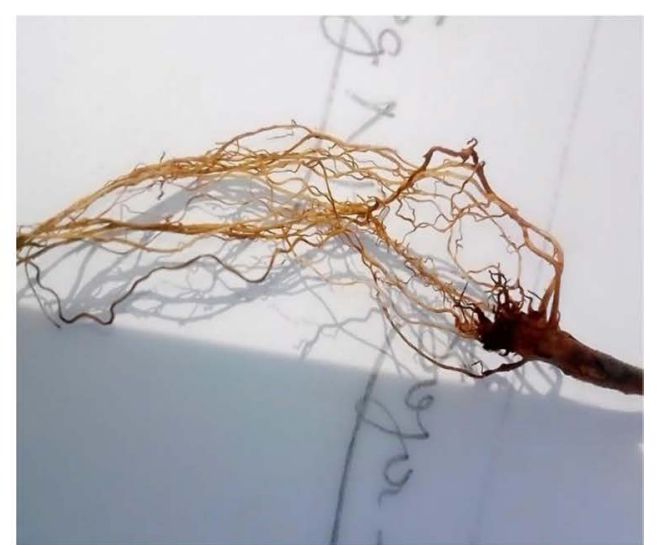

(b)

Figure 6. Photography showing the influence of mineral fertilization on the nodulation capacity of soybean. (a) Soybean grown without mineral fertilizer; (b) Fertilized soybean. 
at soybean grown with $2 \mathrm{~g}$ of nitrogen-phosphorus respectively $(0.16 \pm 0.57$ and $7.89 \pm 6.28$ ) (Figure 6(b)). The number of nodules is statistically identical for soybeans grown with nitrogen ( $2 \mathrm{~g}, 4 \mathrm{~g}$ and $6 \mathrm{~g}), 6 \mathrm{~g}$ of phosphorus and nitrogen-phosphorus ( $4 \mathrm{~g}$ and $6 \mathrm{~g}$ ). As for the length of the plant, it is significantly identical between the soybean grown with $2 \mathrm{~g}$ of nitrogen, $4 \mathrm{~g}$ of nitrogen, as well as $4 \mathrm{~g}$ of nitrogen, $2 \mathrm{~g}$ of phosphorus, and $6 \mathrm{~g}$ of phosphorus. Soybeans grown with $4 \mathrm{~g}$ of nitrogen, $2 \mathrm{~g}$ of phosphorus and $4 \mathrm{~g}$ of phosphorus are significantly identical for the length of the root system. However, soybean grown without mineral fertilizers obtained the highest average $(28.16 \pm 9.42)$, while that grown with $4 \mathrm{~g}$ of nitrogen-phosphorus expressed the lowest average $(10.50 \pm 11,16)$. The weight of the plant and that of the root system were not influenced by mineral fertilization.

\subsection{Discussion}

The results obtained in our study showed that nodulation is influenced by mineral fertilization (nitrogen, phosphorus and nitrogen-phosphorus). The number of nodules depends on the type of fertilizer applied. However, our results are in contradiction with those of Yeboah [8] who found that NPK mineral fertilization in particular and chicken droppings in no way influence the number and weight of nodules. This difference would be due to the fertilizer doses applied. In summary, our data indicate low nodulation in the presence of nitrogen fertilization. Indeed, according to Uddin and al. [9], the number and size of nodules are greatly reduced in the presence of nitrogen in the soil. This decrease in the number of nodules for nitrogen fertilization may be due to the fact that the increase in the number of legume nodules is a function of the lack of nitrogen in the soil. When the soil is low in nitrogen, the activity of nitrogen fixation is intense, which favors the increase in the number of nodules to achieve this activity. On the other hand, when the soil is already rich in nitrogen, the legume prefers to use this available nitrogen in the soil. It follows a decrease in the fixation of atmospheric nitrogen, thus a significant reduction in the number of nodules. These results corroborate those of Zahran [5]. For this researcher, high soil nitrogen levels reduce nodulation and nitrogen fixation. Our results showed that the number of nodules decreases with phosphate fertilization. These results are contrary to those obtained by Bado [6]. In his work, he has proved that phosphorus, dolomite and manure increase nodulation Qiao and al. [7] point out that the lack of phosphorus in soil reduces the number and mass of nodules as well as the activity of nitrogenase in legumes. The work of Shakla \& Yadav [10] under greenhouse conditions on sandy-clay soil on chickpeas showed that the number of nodules and their hemoglobin content increased with increasing phosphorus doses up to $50 \mathrm{ppm}$ and decreased beyond this value. According to Pandey \& Mcintosh [11], phosphorus intake increases the amount of nitrogen fixed by nodules and its concentration in the plant. This difference would be due to the high concentration of phosphorus applied in our study. For nitrogen-phosphorus ferti- 
lization, our results also showed a decrease in the number of nodules. These results corroborate those of Qiao and al. [7]. For these authors, high nitrogen-phosphorus concentrations have an antagonistic effect on nitrogen inhibition. Nitrogen fixation parameters, number of nodules, dry matter of nodules and specific nitrogenase activity were six times higher in high nitrogen and high phosphorus plants than in high nitrogen plants low phosphorus. In our study, the most important plant length and plant weight were obtained in fertilized soils. These results are consistent with those of Dugje and al. [12]. For these researchers, an excess of nitrogen fertilizer will lead to abundant vegetative growth but low seed production. Regarding the length and weight of the root system the most important were obtained at unfertilized soils. These results are supported by Skene [13] who argues that plants have developed strategies to assimilate $\mathrm{Pi}$ (inorganic phosphorus) with greater efficiency in soils depleted in this element. These strategies consist of an increase in root growth and then the establishment of specialized bodies.

\section{Conclusion}

The general objective of our study was to promote cultural practices that can improve the nodulation capacity of legumes. In this study, it was shown that mineral fertilization of legumes negatively affects nodulation. Thus, growing legumes without adding mineral fertilizers gave a high number of nodules. However, a dose of less than $2 \mathrm{~g}$ of phosphorus at the beginning of growth of legumes is important. Therefore, the development of legume crops with a low dose of phosphorus would be a way to enrich the soil with nutrients in order to benefit the crops that will succeed.

\section{Acknowledgements}

Our thanks go to the authorities of the University Jean Lorougnon GUEDE and the teachers of the laboratory of improvement and plant production for the efforts made in carrying out this work.

\section{Conflicts of Interest}

The authors declare no conflicts of interest regarding the publication of this paper.

\section{References}

[1] Chalk, P.M. (1998) Dynamics of Biologically Fixed N in Legume-Cereal Rotations: A Review. Australian Journal of Agricultural Research, 49, 303-316. https://doi.org/10.1071/A97013

[2] Zougmoré, R. (1999) Plantes de couverture et lutte contre l'érosion des sols: Test decomportement d'espèces de légumineuses dans la zone centre du Burkina Faso. In: Carsky, R.J., Etéka, A.C., Keatinge, J.D.H. and Manyong, V.M., Eds., Plantes de couverture et gestion des ressources naturelles en Afrique occidentale, Actes de l'atelier, Octobre, 1999, Cotonou (Benin), 214-220. 
[3] Taffouo, V.D., Ndongo, D.J.E., Nguelemeni, M.P., Eyambé, Y.M., Tayou, R.F. and Akoa, A. (2008) Effets de la densité de semis sur la croissance, le rendement et les teneurs en composés organiques chez cinq variétés de niébé Vigna unguiculata (L). Walp. Journal of Applied Biosciences, 12, 623-632.

[4] Yao, Y., Gao, B., Zhang, M., Inyang, M. and Zimmerman, A. (2012) Effect of Biochar Amendment on Sorption and Leaching of Nitrate, Ammonium, and Phosphate in a Sandy Soil. Chemosphere, 89, 1467-1471. https://doi.org/10.1016/j.chemosphere.2012.06.002

[5] Zahran, H.H. (1999) Rhizobium-Legume Symbiosis and Nitrogen Fixation under Severe Conditions and in an Arid Climate. Microbiology and Molecular Biology Reviews, 63, 968-989.

[6] Bado, B.V. (2002) Rôle des légumineuses sur la fertilité des sols ferrugineux tropicaux des zones guinéenne et soudanienne du Burkina Faso. Thèse de doctorat, Université Laval-Québec, 197 p.

[7] Qiao, W.H., Zhao, X.Y., Li, W. and Zhang, X.Y. (2007) Overexpression of AeNHX1, a Root-Specific Vascuolar Na+/ H+ Antiporter from Agropyron Elongatum, Confers Salt Tolerance to Arabidopsis and Festuca Plants. Plant Cell Reports, 26, 1663-1672. https://doi.org/10.1007/s00299-007-0354-3

[8] Yeboah, G. (2013) Effects of NPK and Poultry Manure Rates on the Growth, Nitrogen Fixation and Grain Yield of Soybean (Glycine max (L) Merrill). Thesis for Master degree BSc. Natural Resources Management (Hons); DipEd., Faculty of Agriculture of the College of Agriculture and Natural Resources, Kwame Nkrumah University of Science and Technology, Kumasi, Ghana, 57 p.

[9] Uddin, M.B., Khan, M.A.S., Mukul, S.A. and Hossain, M.K. (2008) Effects of Inorganic Fertilizers on Biological Nitrogen Fixation and Seedling Growth of Some Agro Forestry Trees in Bangladesh. Journal of Forestry Research, 19, 303-306. https://doi.org/10.1007/s11676-008-0054-Z

[10] Shakla, V. and Yadav, O.P. (1986) Improving Productivity in Rainfed Areas through Balanced Fertilisation in Proceedings of Fertilizer Association of India Seminar. Institut Mondial of Phosphate, New Delhi, 443-456.

[11] Pandey, R.K. and Mclntosh, J.L. (1990) Phosphorus Requirements and Management of Grain Legumes in Phosphorus Requirements for Sustainable Agriculture in Asia and Oceanic. International Rice Institute, 37-361.

[12] Dugje, I.Y., Omoigui, L.O., Ekeleme, F., Kamara, A.Y. and Ajeigbe, H. (2009) Production du niébé en Afrique de l'Ouest: Guide du paysan. Document de l'IITA, $20 \mathrm{p}$.

[13] Skene, K.R. (1998) Cluster Roots: Some Ecological Considerations. Journal of Ecology, 86, 1060-1064. https://doi.org/10.1046/j.1365-2745.1998.00326.x 